\title{
PALEOHYDROLOGICAL FLUCTUATIONS AND STEPPE VEGETATION AT THE LAST GLACIAL MAXIMUM IN THE CENTRAL EBRO VALLEY (NE SPAIN).
}

Blas L. Valero-Garcés ${ }^{1}$, Penélope González-Sampériz ${ }^{1}$, Ana Navas ${ }^{2}$, Javier Machín ${ }^{2}$, Antonio Delgado-Huertas ${ }^{3}$, Jose Luis Peña-Monné ${ }^{4}$, Carlos Sancho-Marcén ${ }^{5}$, Tony Stevenson 6 \& Basil Davis 7

(1) Pyrenean Institute of Ecology - CSIC, Avda Montañana 1005, Apdo 202, E- 50080 Zaragoza, Spain E-mail: blas@ipe.csic.es;

(2) EEAD -CSIC, Apdo 202, E- 50080 Zaragoza, Spain;

(3) EEZ- CSIC, Prof. Albareda 1, E-18008, Granada, Spain,

(4) Dpto. de Geografía. Universidad de Zaragoza

(5) Dpto. de Ciencias de la Tierra. Universidad de Zaragoza.

(6) Department of Geography, Newcastle University, Newcastle upon Tyne, NE1 7RU, UK;

(7) IMEP, CNRS UPRES, Centre Universitaire d’Arles, 13200, France. 


\section{ABSTRACT}

Combined sedimentary facies, geochemical analyses and pollen spectra from lake records and sedimentological and palynological studies from slope deposits allow the characterization of vegetation and lake level status during glacial times in the central Ebro valley (NE Spain). These records show the presence of some increased effective moisture periods while regional vegetation was dominated by steppe taxa. The longest lake record comes from La Salineta, one of the saline lake in the Los Monegros area; the other lake sequence comes from a sinkhole in the Gállego river floodplain. The slope deposit from Valmadrid is the only periglacial deposit found in the central Ebro valley. Our data indicate that - at least for some intervals during full glacial times - when cold steppe vegetation dominated the region, some lakes experienced more positive water balance than today and run-off was also high. The data are coherent with the hypothesis that - at least for some periods- the ice-age climate of the western Mediterranean was characterized by cold winters, relative intense winter precipitation and summer droughts. Increased flow from the Pyrenean rivers during the early deglaciation could also play a significant role in the paleohydrological conditions in the central Ebro valley. However, La Salineta records also show the occurrence of arid periods during glacial times, indicating a complex picture of hydrological and moisture evolution in the central Ebro valley during the LGM.

Key words: glacial, vegetation, lake, isotope, Mediterranean. 


\section{INTRODUCTION}

Evidence for higher-than-present lake levels and steppe vegetation during the millennia around the Last Glacial Maximum have been described in several records from the northern Mediterranean, particularly the central and eastern regions (Prentice et al., 1992; Roberts \& Wright, 1993; Yu \& Harrison, 1995). The apparent conflict between semi-arid conditions indicated by the pollen assemblages and increased effective moisture as shown by lake level reconstructions has been solved by postulating changes in rainfall seasonality as the main factor controlling moisture availability and vegetation. The drying effect of the cold North Atlantic Ocean during glacial times could be counteracted in this paleoclimate scenario characterized by summer-dry and winter-wet regime and an increase in the storm frequency under a southward-shifted jet stream (Prentice et al., 1992). In the eastern Mediterranean there are also evidences for high lake levels in Lake Lisan (the precursor of the Dead Sea) (Stein et al., 1997). In Soreq Cave (Israel) during the 25-17 ka BP period, a substantial growth of speleothems occur, in contrast with many studies that show zero to very little growth in northern countries during glacial times (Bar-Mattews et al., 1997).

The evidence for high lake levels in some of these records from eastern sites (Lake Ioannina and Lake Xinias in Greece, for example) has been challenged recently and it has been suggested that both pollen and lake level record indicate dry climate conditions during the LGM in the Mediterranean (Tzedakis, 1994; Digerfeldt et al., 2000). In most of the Mediterranean region there is a shortage of accurate data, both reliable paleohydrological proxies as accurate radiocarbon dates, and at present, regional reconstruction are heterogeneous and sometimes contradictory. More records need to be available to allow reconstruction of glacial climate in the Mediterranean. To contribute to this purpose, we describe in this paper several records from northeastern Spain containing deposits from glacial times.

Glacial pollen spectra from Spanish sites are characterized by Artemisia, grasses, Chenopodiaceae, Asteraceae and Ephedra distachya (Navarrés, Carrión \& Dupré, 1996; Padul, Pons \& Reille, 1988; Banyoles, Pérez-Obiol and Julià, 1994; Carihuela Cave, Carrión et al., 1998) as in many full-glacial floras from other European records (Huntley et al., 1999; Allen et al., 1999). In Banyoles, the Artemisia steppe vegetation during the LGM reflects cold 
and arid conditions (Pérez-Obiol \& Julià, 1992), although the presence of laminated, relatively deeper lacustrine facies and a sharp negative $\delta^{18} \mathrm{O}$ excursion suggests increased water balance in the lake (Valero-Garcés et al., 1998). In the Mediterranean regions of the Iberian Peninsula, available effective moisture has been a major factor controlling vegetational and environmental changes during the Lateglacial and Holocene (Huntley, 1988; Huntley \& Prentice, 1993). This is particularly true in semi-arid regions as the central Ebro valley, the most northerly area of truly semi-arid climate in Europe. Environmental, vegetational, cultural and climate conditions in the Central Ebro valley during glacial times are unknown due to the lack of paleorecords covering that period. Archaelogical sites ascribed to Lateglacial times (Magdalenien) occur in the Pre-Pyrenees, in the Iberian Range and in strategic sites as natural corridors between the Spanish Central Plateau and the Ebro Basin, or close to thermal areas (Utrilla \& Rodanés, 1997). The absence of Lateglacial archaelogical sites in the Ebro Basin has been traditionally explained as a combination of the low impact on the landscape of the gatherers-hunters and the disappearance of the sites by erosion and burial. Although there are numerous lacustrine records in the Spanish Central Pyrenees (Montserrat, 1992; Jalut et al., 1992), and in the Ebro valley (Davis, 1994; Valero-Garcés et al., 2000a,b,c), most of them only cover the Lateglacial and Holocene history of the region. Basal AMS ${ }^{14} \mathrm{C}$ dates from glacial lakes associated to moraines in the Gállego river headwaters indicate that the upper Gállego River was already deglaciated during the global Last Glacial Maximum (1820 kyrs) (González-Sampériz et al., 2001), and that mountain vegetation was a cold steppe. Lake sequences from the abundant saline lakes in the Ebro basin could potentially provide long records including glacial stages. Several studies have shown the potential and limitation of lacustrine records in the Ebro Basin for paleoclimate reconstructions (Davis, 1994; Burjachs-Casas et al., 1996; Schütt, 1998; Valero-Garcés et al., 2000 a,b,c). Paleoenvironmental and paleoclimatic interpretations of these records are complicated by the presence of numerous hiati, caused by deflation and erosive processes, and the complexity of evaporite deposition and early diagenesis.

In this paper we present palinological, sedimentological and geochemical data from two lake records and one slope deposit in the Central Ebro valley that include sedimentary units deposited during glacial times (18-30 ka) and we integrate them with available glacial 
paleorecords from the Ebro Basin. The longest lake record comes from La Salineta, one of the saline lake in the Los Monegros area; the other lake sequence comes from a sinkhole in the Gállego river floodplain, close to the town of San Juan de Mozarrifar. The slope deposit from Valmadrid is the only periglacial deposit found in the central Ebro valley. Our data indicate that - at least for some intervals during full glacial times - when cold steppe vegetation dominated the region, some lakes experienced more positive water balance than today and run-off was also considerably higher. The similarity of these results compared to paleoclimate reconstructions from the central and eastern Mediterranean regions favors changes in seasonality as the main factor driving moisture availability in the Mediterranean.

\section{GEOGRAPHIC AND CLIMATE SETTING OF THE CENTRAL EBRO VALLEY}

The climate in the Central Ebro valley is Mediterranean with a strong continental influence, and it is characterized by very hot summers, cold, dry winters, and low rainfall (300 - 350 mm/yr, Capel-Molina, 1981) (Fig. 1A). The high insolation and evapotranspiration (1000 - $1500 \mathrm{~mm} / \mathrm{year}$ ), and the prevalence of strong dry NW winds also contribute to a water deficit through the year, especially during the summer. Rainfall is irregularly distributed, although spring and fall precipitation accounts for more that $70 \%$ of the total annual rainfall. The central Ebro valley is a steppe, mostly dedicated to agriculture, with some small areas dominated by Pinus halepensis, Quercus coccifera, and Juniperus (Blanco et al., 1997).

The Central Ebro valley contains many shallow, saline lake basins, particularly in the central plateau of Los Monegros and in the Bajo Aragón area (Pueyo-Mur, 1979; Figure 1B). The brines are of $\left(\mathrm{Cl}^{-}\right)-\left(\mathrm{SO}_{4}{ }^{=}\right)-\left(\mathrm{Na}^{+}\right)-\left(\mathrm{Mg}^{2+}\right)$ type and undergo strong seasonal oscillations in concentration because of groundwater input, evaporation and progressive salt precipitation. The genesis of the depressions has been related to dissolution of the Tertiary evaporite substrate, preferential water circulation through fault lines, differential erosion, and surface deflation (Pueyo-Mur, 1979; Benito et al., 1998; Sánchez-Navarro et al., 1998). Three sedimentary lacustrine units and two main aquifers have been defined in the Late Oligocene and early Miocene evaporite-bearing formations underlying the hydrologically-closed basin of Los Monegros (García-Vera, 1996). Most of the lakes are located in the Intermediate unit, and only a few (La Salineta among others) occur in the Upper lacustrine unit, north of the main Los Monegros endoreic system. La Salineta lake is located $1.5 \mathrm{~km}$ south of the town of 
Bujaraloz at an altitude of $325 \mathrm{~m}$ a.s.l. The present lake is a seasonal playa lake that holds water longer than most of the other lakes. Water chemistry is dominated by sodium-chloride and salinities can reach values up to $200 \mathrm{~g} / \mathrm{L}$. A thick, soft and wet halite crust covers the surface during the summer. Groundwater is typically of magnesium-sulfate or calcium sulfate type with and average TDS of $5 \mathrm{~g} / \mathrm{L}$. Stable isotope (García-Vera, 1996) data suggest that groundwater, rainwater, and runoff (estimated in less than $10 \%$ of the rainfall) are the main water input to the lakes (Samper-Calvete \& García-Vera, 1998). Groundwater recharge takes place at the interfluves and highlands and its range is estimated from 20-45 mm/yr. Hydrological modeling suggests that the upper aquifer discharges one third of the total recharge $\left(5822 \mathrm{~m}^{3} / \mathrm{yr}\right)$ into La Salineta Lake, and that the lower aquifer contributes with waters with long residence times and high chloride and sodium contents. This hydrology explains both the perennial nature of the lake and the presence of the thickest salt layers (Samper-Calvete \& García-Vera, 1998).

The modern La Salineta lake (20 ha surface) is inset within a much larger paleolake, whose deposits have been eroded and form cliffs up to $4 \mathrm{~m}$ surrounding the present lake. The cliffs are well developed at the windward southeastern end of the basin. The paleolake sediment surface sits almost level with the rolling plains of the steppe and it is visible over the ploughed ground as an area of grey lacustrine clays. In some short section, remains of small cliff (1 $\mathrm{m}$ high) marks the boundary of the maximum extent of the lake. Natural vegetation is very restricted by the dominance of winter wheat farming in the surroundings of the lake. Halophytes surround the shore and algal mats cover the lake bottom and are more visible when the halite crust re-dissolves with the autumn rains.

The San Juan de Mozarrifar Sequence is located close to the city of Zaragoza (220m a.s.l., $41^{\circ} 44^{\prime} 35^{\prime \prime} N$ and $2^{\circ} 51^{\prime} 50^{\prime \prime} \mathrm{W}$ ), in the Quaternary floodplain and terrace deposits of the Gállego river, a tributaire of the Ebro river. The fluvial deposition of the Gállego River in this area has been strongly influenced during the Late Quaternary by subsidence and collapse processes affecting the underlying Miocene gypsum and evaporite substrate (Benito et al., 1998). As a consequence, the Gállego terrace system is complex, with large thickenings of the fluvial deposits, large-scale deformation structures and smaller topographic depressions, some of them still active (Benito et al., 1998). Due to the incision of the Gállego river channel 
caused by the 1996 flooding, several paleo-depressions were unraveled in the floodplain area close to the town of San Juan de Mozarrifar. One of them allowed a detailed study of the three-dimensional geometry and the nature of the deposits.

The Torrecilla de Valmadrid scree is the only stratified slope deposit identified in the central Ebro basin. In the Pyrenees and in the Iberian Range stratified slope deposits (screes) are common (García-Ruiz et al., 2001). They are widely considered indicative of the lower limit of the periglacial belt and reflect relict morphoclimatic cold conditions. The Torrecilla de Valmadrid scree is located about $25 \mathrm{~km}$ south of Zaragoza in a narrow E-W trending gorge carved in Jurassic paleo-relief. The cliff height is about $100 \mathrm{~m}$ from $676 \mathrm{~m}$ at the top to $570 \mathrm{~m}$ at the bottom of the gorge and it is composed of alternating matrix-supported beds and coarser, openwork layers with clasts.

\section{METHODOLOGY}

An outcrop with paleolake sediments located in the southeastern cliff of La Salineta was described and sampled every $10 \mathrm{~cm}$ in 1991 (Davis, 1994). The analyses performed in this $465 \mathrm{~cm}$ long section included pollen, charcoal, macrofossils and geochemistry, and the results are described in detail elsewhere (Davis, 1994). A new $8 \mathrm{~m}$ long core was drilled in the cliff close to the previous section. It provides the longest lacustrine record available in the central Ebro valley. The core reached the substrate composed of Miocene Limestone. The sediment core was split, described, and sampled for organic matter, mineralogy, geochemistry, stable isotope, and pollen analyses following methods described elsewhere (Valero-Garcés et al., 2000b). Sedimentological and geochemical analyses provided the basis for facies identification and unit definition in the core. No terrestrial organic remains were found in the core, and the chronology is constrained by four AMS ${ }^{14} \mathrm{C}$ dates on organic matter concentrates. The San Juan de Mozarrifar lacustrine sequence and the Valmadrid slope deposits were measured and described in the field and sampled for pollen studies and radiocarbon dating.

\section{RESULTS}

\section{CHRONOLOGY}

Reliable chronologies for saline lake sequences in the Ebro basin have been hindered by the scarcity of terrestrial macrofossils for radiocarbon dating (Davis, 1994; Burjachs-Casas 
et al., 1996; Schütt, 1998; Valero-Garcés et al., 2000). The presence of large organic remains in the San Juan de Mozarrifar sequence is a unique occurrence. A minimum conventional radiocarbon age of $28000{ }^{14} \mathrm{C}$ yr B.P. was obtained from a conifer trunk in this sequence (Table 1). Organic macrorests were very scarce in La Salineta. Chenopodiaceae seeds from the upper $20 \mathrm{~cm}$ of the La Salineta section (Davis,1994) gave a modern AMS age likely caused by soil contamination, and consequently the chronology of this section is unknown. The presence of Fagus at the base of the section $(320 \mathrm{~cm})$ suggests a Late Holocene age. Fagus does not appear until 3.0 Kyr at other sites like Salada Pequeña and it is not found at any of the early Holocene sites in the Ebro Basin (Davis, 1994). The earliest Fagus appears on the Spanish side of the Pyrenees is around 5 Kyr (Montserrat, 1992).

The upper $2 \mathrm{~m}$ of the La Salineta core are affected by farming and modern edaphic processes and, consequently, were not sampled because carbon contamination is likely. The only organic macrorest found in the core was located at 184-186 cm depth and it provided a modern radiocarbon age. Because the organic matter content was also very low, bulk samples were treated as palynological samples to concentrate the organic particles and to check under the microscope the composition of the remaining organic fraction. Pollen grains were very scarce and the organic fraction was mostly composed of micro-charcoal particles. An internally consistent chronological framework has been developed, based on several AMS ${ }^{14} \mathrm{C}$ dates. The validity of these dates has to be discussed, particularly related to hard-water effects and contamination by old carbon. The presence of lacustrine organic matter remains and aquatic plant pollen in the samples could produce a hard-water effect. Although it cannot be completely ruled out, hard-water effects are unlikely in these samples, since they seem to be mostly composed of charcoal and the aquatic organic fraction is mostly destroyed during the treatment. The microscope checks of the concentrates indicate that the presence of unidentified particulate organic matter is very small. The age of the upper sample (209-211 $\mathrm{cm}$ depth) is too old compared with the underlying samples and its validity is arguable. The coarser, more massive nature of the sediments suggests increased aeolian activity in the upper units and that could have resulted in contamination from older carbon particles. This sample has not been included in the chronological framework constructed for this paper. 
Pollen concentrates have provided enough material for AMS dating in organic-poor deposits in several sites from the Pyrenees and the Ebro Basin (Valero-Garcés et al., 2000; García-Ruiz et al., 2001) and this technique was used to date the scree deposits of Valmadrid. The pollen concentrates were obtained following the same chemical method used to prepare palynological samples. Two paired samples were prepared at each level to study the palynological composition, and to check for other organic remains that could contaminate the samples. The presence of small amounts of thermophilous pollen grains is considered an indication of long distance transport from the refuges in the Ebro valley (Valero-Garcés et al., 2000). The similar conservation stage of all the pollen grains and the absence of any $\underline{\text { indication of secondary reworking also favored a synchronous deposition of all pollen grains }}$ and long distance rain. The ${ }^{14} \mathrm{C}$ AMS date from the pollen concentrate at the base of the scree was $17100 \pm 85$ years BP (Table 1). EN MI OPINION, ESTE PARRAFO NO QUEDA DEMASIADO CLARO PORQUE PARECE QUE LO QUE INTERESA AHORA SON LAS FECHAS, Y SIN EMBARGO SE MEZCLAN ALGUNOS RESULTADOS POLINICOS, QUE APARECEN SIN EMBARGO MAS TARDE OTRA VEZ, EN EL APARTADO DE VALMADRID, CON LOS RESULTADOS GENERALES. QUITARIA TANTO LO DE LA CONSERVACION POLINICA COMO LO DE LOS REFUGIOS.

\section{LA SALINETA}

The Pollen Record. A detailed description of a $4.65 \mathrm{~m}$ long section located in the southeastern cliff of La Salineta can be found in Davis (1994). The record suggests seasonal playa-lake environments and a change in the regional vegetation from Pinus \& Quercus ilextype woodland and grass steppe to a Pinus \& Juniperus woodland. The disappearance of Juniperus and the onset of Olea could reflect the Medieval expansion of olive trees. However, pedogenic processes are likely to have affected the sedimentological and palynological record of the top meter of the outcrop.

Pollen preservation in the $8 \mathrm{~m}$ long core was very low, and below $2.5 \mathrm{~m}$ depth the samples were sterile. Pollen analyses in the upper sections indicate a regional vegetation dominated by Pinus and a variable content of Chenopodiaceae reflecting changes in lake surface (Fig. 2). The presence of Gramineae also supports anthropogenic influence. NO 
DE Cerealia type PERO NUNCA DE GRAMINEAS. SE CITA Gramineae o Poaceae CUANDO SON SILVESTRES, Y ENTONCES JAMAS INDICAN ACCION ANTROPICA. SUGIERO CAMBIAR GRAMINEAE POR CEREALIA TYPE.

\section{The Sedimentary and Geochemical Record.}

Five main sedimentary units have been defined in the La Salineta core based on sedimentological, lithological and geochemical criteria (Fig. 3). Depositional environments for saline lake sediments can be identified integrating a variety of criteria (see Valero-Garcés et al., 2000 for a more extensive description and references): increased dolomite content commonly reflects higher $\mathrm{Mg} / \mathrm{Ca}$ ratios in more concentrated waters; occurrence of microcrystalline gypsum laminae suggest periods of higher sulfate concentration; higher organic matter contents indicate higher biological productivity and better preservation conditions (less oxidant). Because of the low carbonate content, calcium concentrations mostly reflect gypsum content. The chemical elements associated to clays ( $\mathrm{Al}, \mathrm{K}$, and $\mathrm{Mg}$ ), oxides $(\mathrm{Fe}, \mathrm{Mn})$ and saline minerals $(\mathrm{Na})$ show similar patterns and are interpreted as indicative of more frequent desiccation stages in the lake leading to saline mineral precipitation, oxide formation and clay deposition. Unit 5 is composed of dark greenish gray, massive to faintly banded calcitic and gypsum-rich muds with some $\mathrm{cm}$-long limestone clasts from the Miocene substrate. The high carbonate and relatively high organic matter contents, and the presence of calcite as the only carbonate mineral in Unit 5B suggest a short period of less concentrated lake waters and higher organic productivity immediately after the genesis of the lake basin. This interpretation is coherent with higher rainfall conducive to increased karstic activity. Decreasing carbonate content and appearance of dolomite mark a rapid transition during Unit $5 \mathrm{~A}$ to progressively more concentrated waters and more frequent desiccation periods. Unit 4 is composed of massive, dolomitic muds with abundant gypsum crusts. More abundant gypsum, occurrence of dolomite as the only carbonate phase, low organic matter and carbonate contents and high $\mathrm{Mn}$ and $\mathrm{K}$ concentrations are indicative of deposition in ephemeral saline lake environments during unit 4. The trend to increasing carbonate (dolomite) and organic matter content at the top of unit 4 could reflect more frequent flooded episodes in the lake. 
The large change in sediment composition defined by the onset of unit 3 is likely to reflect a sedimentary hiatus. Increased presence of gypsum laminae composed of microcrystals and occurrence of both, calcite and dolomite characterize this unit. Sediments show the highest organic matter content and lower values of some saline indicators $(\mathrm{Na}, \mathrm{K})$. A relatively more positive water balance and lower water salinity is inferred for this unit. They are interpreted as deposited in a semi-permanent saline lake with periods of increased water concentration (gypsum deposition). Sediments from unit 2 are massive, without gypsum laminae, crusts or macrocrystalline gypsum occurrences. Basanite and gypsum co-exists in the lower part of the unit and basanite remains the only sulfate at the top. Organic content in unit 2 is the highest of the core. The top of unit 2 is marked by a sharp decrease in organic matter and carbonate content indicative of a large limnological change. Unit 1 is composed of massive, porous sediments with abundant saline efflorescences and edaphic features (mottling, roots). The chemical elements associated to clays (Al, $\mathrm{K}$, and $\mathrm{Mg}$ ), oxides (Fe, Mn) and saline minerals $(\mathrm{Na})$ show similar patterns and higher values. These features could be related to modern soil processes.

\section{The Isotope Record.}

A large range (between -5 and $+5 \%$ ) characterizes the $\delta^{18} \mathrm{O}$ curve for the La Salineta carbonate samples (Figs. $3 \& 4$ ). The lowest oxygen compositions (between - 5 and $3 \%$ ) occur in unit 5 . Isotope values increase at the base of unit 4 and remained high (+3 to $+5 \%$ ) till the top of this unit. Unit 3 inaugurates with a negative shift and it shows a lower part characterized by relatively higher and more variable values with two main positive excursions (500- $530 \mathrm{~cm}$ and around $450 \mathrm{~cm}$ ) and an upper part $(350-440 \mathrm{~cm}$ ) with more negative and constant values (between -3 and $-1 \%$ ). Similar values occur in the upper units 2 and 1 (between 0 and $-3 \%$ ).

The $\delta^{13} \mathrm{C}$ carbonate record show three distinctive intervals. Unit 5 has the heaviest $\delta^{13} \mathrm{C}$ (carbonate) compositions. The values in the overlying units 4,3 , and 2 show a small range (-4 to-3\%), and they slightly decrease at the top of the core (unit 1 ). Covariance between oxygen and carbon isotope values is not significant if all the values are considered

(Fig. 4). However is better in Unit 4 and within the group of high $\delta^{18} \mathrm{O}$ values in Unit 3. A 
similar behaviour in other saline lakes suggest that covariance increase during less positive water balance episodes (Talbot, 1990; Valero-Garcés et al., 2000).

Most $\delta^{13} C_{\text {org. }}$ (bulk organic matter) values are smaller than $-24 \%$ suggesting a dominance of terrestrial over lacustrine carbon sources. In other saline lakes in the Ebro basin (Salada Mediana; Valero-Garcés et al., 2000), cyanobacterial mats have considerably heavier values (between -12.8 and $-11.2 \%$ PDB) than terrestrial halophytic plants (between 20 to $-24 \%$ PDB). The $\delta^{13}$ Corg. (bulk organic matter) curve (Fig. 3) show four main intervals: i) high and relatively constant values ( $>25 \%$ ) in unit 5 ; ii) a decreasing trend from -25 to -26 $\%$ in unit 4 ; iii) relatively higher and constant values in units 3,2 and $1 \mathrm{~B}$; and iv) an increasing and then decreasing $(40-0 \mathrm{~cm})$ trend in unit $1 \mathrm{~A}$. The lowest value occurs at the base of unit $1 \mathrm{~A}(-27.2 \%)$, and the highest $(-23.2 \%)$ at the top of unit 4 . Recent edaphic processes may be responsible for the decreasing trend in the upper $30 \mathrm{~cm}$.

\section{THE SAN JUAN DE MOZARRIFAR RECORD}

Five main units have been identified in the San Juan de Mozarrifar sequence (Fig. 5). The basal Unit 1, composed of fluvial gravels, shows an exposed thickness of $3 \mathrm{~m}$. Unit 2 (1.2 $\mathrm{m}$ thick) is composed of sands with some ferruginous thin layers, root structures and treetrunks remains. It is topped by a paleosol horizon with a ferruginous crust. Deposition of this unit occurred in a fluvial environment with long periods of subaerial exposure when edaphic processes took place. The sediment layers show some paleo-depositional slope, common in depositional environments with a slow subsidence synchronous to the infilling of the depression. Pollen samples from this unit were sterile, likely because pollen grains were destroyed in an oxidizing environment. Unit 3 (3.9 m thick) is composed: i) subunit 3A: $1.1 \mathrm{~m}$ of dark grey and black, laminated organic- rich and carbonate-rich silts with abundant gastropods, root structures and "in situ" conifer tree trunks and roots. One of this tree roots has been dated as $>28000{ }^{14} \mathrm{C}$ yr B.P. (Table 1); ii) subunit 3B: $2.80 \mathrm{~m}$ of black, finely laminated, organic-rich, carbonate muds. Unit 3 represents deposition in a depression generated in the floodplain due to subsidence and collapse of the underlying evaporites. After a period characterized by shallow waters with frequent subaerial exposure and colonization by trees (subunit 3A), a permanent, deeper lake was formed and finely laminated sediments 
were deposited. Unit 4 is composed of massive silts and it lies unconformably over the previous unit. Unit 4 has also been partially eroded by the deposition of gravel and sands of higher Gállego terraces (Unit 5), dated as Holocene by the presence of Elephas tusks.

Pollen samples from unit 3 show a dominance of Pinus and Chenopodiacea that indicates a regional landscape dominated by steppic vegetation. The high Chenopodiaceae content in subunit $3 \mathrm{~A}$ suggests periods of subaerial exposure and colonization of the floodplains and the lakes by grasses. Pollen assemblages in subunit 3B show a relative decrease in Chenopodiaceae, a minor increase in Ephedra t.distachya, Ephedra t.fragilis, Artemisia and Helianthemum and a larger increase in aquatic plants (Potamogeton). All this features indicate more permanent aquatic environments as it was interpreted from the sedimentological record. An increase in water availability would have turned the sinkholes and dolines in the large Gállego floodplain from seasonally flooded during deposition of subunit $3 \mathrm{~A}$ to permanently aquatic system during deposition of subunit 3B. The presence of some pollen grains from temperate trees - some of them currently absent in the Central Ebro valley as Corylus, Alnus and Salix - suggest the existence of small riparian forest in the Gállego and Ebro rivers (Sánchez-Goñi \& Hannon, 1999; Valero-Garcés et al, 2000).

The San Juan de Mozarrifar sequence is an example of the many sinkholes that occurred in the area, reaching up to 12 paleo-depressions per $\mathrm{km}^{2}$. Although only this sequence has been dated, geomorphological criteria suggest their genesis was temporarily restricted to discrete periods. Higher evaporite dissolution and subsidence rates are related to periods of increased river discharge (Benito et al., 1998). Although the dating of this sequence is not accurate, provides an example of the occurrence of periods of increased river flow in the Pyrenean rivers at times of "full-glacial" conditions in northern Europe.

\section{THE TORRECILLA DE VALMADRID SLOPE DEPOSITS}

The Torrecilla de Valmadrid stratified deposits occur in both northern and southern slopes of the cliff. The screes are composed of alternating matrix-supported beds and coarser, openwork layers with clasts up to $8.5 \mathrm{~cm}$ long. The origin of these deposits is related to the presence of the adequate cliff lithology (carbonate), the occurrence of freeze-thaw cycles that generate the clasts, and the existence of several slope processes as debris flow 
activity, creep and wash erosion and intense freezing conditions that caused the grain-size classification (García-Ruiz et al., 2001). One of the three pollen samples was sterile and the upper one contains clear indications of contamination with modern pollen grains. The pollen assemblage (Fig. 6) in the lower sample is mostly composed of Pinus and steppic grasses (about $50 \%$ ). Although Pinus is the dominant tree, other taxa as Juniperus, Quercus t. ilexcoccifera, Rhamnus, Salix and Phillyrea are present. Grasses are dominated by Poaceae, $\underline{\text { Fabaceae and other taxa as Artemisia, Chenopodiaceae and Ephedra t. fragilis, all indicative }}$ of aridity. This pollen spectrum reflects steppic open vegetation, not very different from today's environments. CUIDADO!!!!. Fabaceae NO PUEDE CONSIDERARSE COMO TAXON INDICADOR DE ARIDEZ. O SE ELIMINA DE LA LISTA, O MEJOR, SE REDACTA DE FORMA QUE APAREZCAN COMO PRINCIPALES COMPONENTES DEL ESTRATO HERBACEO Poaceae Y Fabaceae, JUNTO A TAXONES INDICADORES DE ARIDEZ (EL RESTO DE LA LISTA ESTA BIEN), PERO NO TODOS EN EL MISMO SACO, VALE?

An AMS ${ }^{14} \mathrm{C}$ date of a pollen concentrate provides an age of $17100 \pm 8514 \mathrm{C}$ yr B.P. for the onset of the scree formation. The presence of some taxa as Phillyrea, seems noncompatible with the cold conditions needed for the scree formation. However, an increase in continentality and seasonality could explain the presence of periglacial activity during the very cold winters and the occurrence of taxa as Phillyrea during the relatively warmer summers, particularly in some more protected, southern slopes areas of the region.

\section{DISCUSSION AND CONCLUSION}

Combined sedimentary facies, geochemical analyses and pollen spectra from lake records and sedimentological and palynological studies from slope deposits allow the characterization of vegetation and lake level status during glacial times in the central Ebro valley. These records show the presence of some increased effective moisture periods while vegetation was dominated by steppe taxa. Genesis of sinkholes in the central Ebro basin is related to increase dissolution of the evaporite and carbonate substrate (Benito et al., 1998). Some depressions in the Ebro valley originated during the Lower and Middle Pleistocene. However, geomorphologic criteria indicate that many depressions also formed during the Upper Pleistocene (van Zuidam,1980). Periods of increased evaporite dissolution and karstic activity are likely to reflect higher effective moisture and run-off in the central Ebro valley. A 
period of increased river flow prior to 28 ka would be responsible for the genesis of large sinkholes in the Gállego river floodplain like the San Juan de Mozarrifar. Although absolute dates for deglaciation in the Gállego Upper valley are absent, basal dates from glacial lakes (González-Sampériz et al., 2001) indicate that the maximum glacier extent in the Pyrenees occurred earlier than the global LGM when the Scandinavian Ice Sheet and most glaciers in northern Europe reached their maximum. The onset of deglaciation in the Gállego prior to 28 ka would have caused an increased in river flow responsible for increased evaporite dissolution and sinkhole genesis in the lower reaches of the river crossing the Tertiary evaporite formations. Pérez-Obiol and Julià (1994) interpreted peaks in mesothermophilous taxa in Banyoles as an evidence for an interstadial (ESTAS SEGURO DE QUE UTILIZAR EL TERMINO INTERESTADIAL ES LO MAS APROPIADO EN ESTE CASO?) event between 30,000 and 27,000 years B.P. in Mediterranean Spain. However, Carrión et al (1998) do not find any expansion of Quercus in the Carihuela Cave (Granada, Spain) during the interPleniglacial zones and they consider than the Quercus expansion in Banyoles is not more prominent than other peaks in the middle Würm at Padul (Pons \& Reille, 1988). The ascription of these small peaks in mesothermophilous taxa to major warming events is still debatable.

La Salineta lake also originated during glacial times (prior to $23900 \pm 140{ }^{14} \mathrm{C}$ yr B.P.) due to karstification of the underlying Miocene limestone. The base of La Salineta (unit 5) reflects the highest effective moisture period of the whole sequence. Hydrological modeling indicates that because of the low-permeability of the substrate La Salineta closed-basin is very sensitive to changes in groundwater recharge (Samper-Calvete \& García-Vera, 1998). In modern conditions, an increase in groundwater recharge from 20 to $50 \mathrm{~mm} / \mathrm{yr}$ would increase the discharge to the lakes to equal the estimated maximum evaporative capacity and would cause a remarkable water-table rise. Changes in the evaporation ratio would also have a large impact on the water balance. This period of relatively freshwater conditions (Unit 5) was followed by another of increased chemical concentration of the lake waters (Unit 4). This period of more negative water balance in the lake represents the lowest effective moisture period in the whole record, and according with the preliminary chronology, also corresponds to full glacial conditions (prior to $21 \mathrm{ka}$ ). 
There are several evidences for wetter conditions in the Mediterranean than in northern Europe during glacial times. Using the best analogs method, Peyron et al (1998) reconstructed the LGM climate of Europe from pollen data. South of the Pyrenees- Alps, temperatures of the coldest month were $-15 \pm 5^{\circ} \mathrm{C}$ and annual mean temperature was $-10 \pm$ $5{ }^{\circ} \mathrm{C}$; the available moisture index and annual precipitation were lower than present $(-20 \%$ and $-600 \pm 200 \mathrm{~mm}$, respectively). The reconstructions show that the Mediterranean region was relatively wetter than northern Europe during the LGM. A succession of temperate and cold environments in the Iberian Peninsula during a portion of the last glacial period (50-30 ka) has been interpreted from pollen spectra from marine cores off-shore Portugal (SánchezGoñi et al., 2000). Available terrestrial records lack the resolution to identify the impact of these fluctuations in vegetation and moisture balances. However, many terrestrial records document several humid and arid periods since the LGM. Some other Iberian records also suggest periods of increased effective moisture during glacial times. Deep-water sedimentary facies and a large negative $\delta^{18} \mathrm{O}$ excursion in the Banyoles record indicates that immediately after the LGM - dated as $22,890 \pm 310{ }^{14} \mathrm{C}$ yr BP and 18,000 U/Th yr BP - there was a period of increased effective moisture in north-eastern Spain (Valero-Garcés et al., 1998). La Salineta and Salada Mediana (Valero-Garcés et al, 2000 b, c) provide the only available Lateglacial lacustrine records for the Ebro valley. In Mediana, two periods of increased effective moisture, identified by higher lake levels and temperate tree expansion (particularly Corylus), occurred after $18 \mathrm{Ka}$. Palynological evidence for cold climate in the Central Ebro valley during glacial times (around $18 \mathrm{ka}$ ) comes from the Valmadrid slope deposits.

High lake levels in Mediterranean regions during glacial times could also have occurred due to cold winters and cool, cloudy summers that greatly reduce potential evapotranspiration (COHMAP members, 1988). However, a simply reduction of evapotranspiration tends to reduce drought stress on vegetation as well as increasing run-off. The apparent contradiction between steppe vegetation in the Ebro basin during glacial times (30-18 ka) synchronous with periods of increased run-off in the Pyrenean rivers and more positive water balance in the central plateau of Los Monegros is caused by the sensitivity of lake levels and vegetation to different components of the water balance. Vegetation in Mediterranean environments tends to equilibrium such that evapotranspiration during the wet periods (winters) conserves enough 
water to survive through dry periods (summer) (Prentice et al., 1992). Lake levels in shallow lakes dominated by surface aquifers are particularly sensitive to changes in run-off from the catchment. A soil water-balance model (Prentice et al., 1992) showed that combining winter cooling with a redistribution of the same total annual precipitation (increase in winter and decrease in summer) and potencial evapotranspiration can increase run-off at the expense of soil moisture causing an increase in percolation and lake levels and a reduction in vegetation cover.

GCMs experiments indicate that temperatures in the Mediterranean region were 5-10 ${ }^{\circ} \mathrm{C}$ lower than present in winter due to strong westerlies from the cold North Atlantic, and only $1-3^{\circ} \mathrm{C}$ lower in summer because of local heating and weaker westerlies (Kutzbach et al., 1993). Harrison et al (1996) explained the LGM climate by the development of anticyclonic circulation over the Scandinavian Ice Sheet, and a southward displacement of the westerly jet. Most models show a year-round strengthening of the jet stream, and increased winter precipitation along the jet stream close to the latitude of the Mediterranean. High paleoproductivity during the LGM in the Alborán Sea also indicates stronger westerlies in the Western Mediterranean (Bárcena et al., 2001). The marine records from the Alborán Sea also show a moister episode from 18.5 to $17.3 \mathrm{kyr}$ B.P. Relatively warmer sea-surface temperatures for the time around the LGM have been interpreted in core SO75-6KL, offshore Portugal based on dinoflagellate cyst (Boessenkool et al., 2001). As the jet stream retreated northward, the source of additional winter precipitation was removed and annual precipitation remained low because of the cold North Atlantic; lake levels in eastern Mediterranean fell to a minimum during Late glacial times. In Iberia, the Lateglacial effective moisture fluctuations have been linked to a southwards displacements of the Atlantic oceanic polar front, the Azores high and the Mediterranean winter belt (Harrison et al., 1996; Gasse 2000).

The paleoenvironmental reconstructions from these three records from NE Spain show the occurrence of periods of increased effective moisture and run-off in the central Ebro valley during glacial times when vegetation was a cold steppe. The data are coherent with the hypothesis that - at least for some periods- the ice-age climate of the western Mediterranean was characterized by cold winters, relative intense winter precipitation and summer droughts. Increased flow from the Pyrenean rivers during the early deglaciation could also play a 
significant role in the paleohydrological conditions in the central Ebro valley. However, La Salineta records also show the occurrence of arid periods during glacial times, indicating a complex picture of hydrological and moisture evolution in the central Ebro valley during the LGM. To solve the controversies of the glacial climate in the Mediterranean region during glacial times a network of well-dated records analyzed with a variety of paleohydrological proxies is needed.

\section{ACKNOWLEDGEMENTS}

The research in the central Ebro valley was funded by the Aragonese Regional Government (Project PO23/2001: "Environmental evolution and human impact in the Bujaraloz-Sástago lake complex. Scientific bases for conservation and sustainable development of the Los Monegros saline lakes"), and the Spanish Government (CICYT Project REN2000 "Arid Periods in the Mediterranean areas of the Iberian Peninsula since the Last Glacial maximum: Chronology, characterization and paleoclimate implications" ). 


\section{REFERENCES}

Allen, J.R.M., Brandt, U., Brauer, A., Hubberten, H.-W., Huntley, B., Keller, J., Kraml, M., Mackensen, A., Mingram, J., Negendank, J.F.W., Nowaczyck, N.R., Oberhänsli, H., Watts, W.A., Wulf, S. and Zolitscha, B., 1999. Rapid environmental changes in southern Europe during the last glacial period. Nature 400, 740-743.

Bárcena, M.A., Cacho, I., Abrantes, F., Sierro, F.J., Grimalt, J.O. \& Flors, J.A., 2001. Paleoproductivity variations related to climatic conditions in the Alboran Sea (western Mediterranean) during the last glacial-interglacial transition: the diatom record. Palaeogeography, Palaeoclimatology, Palaeoecology 167, 337-357.

Bar-Matthews, M. \& Ayalon, A., 1997. Late Quaternary paleoclimate in the Eastern Mediterranean region from stable isotope analysis of speleothems at Soreq Cave, Israel. Quaternary Research 47: 155-168.

Benito, G., Pérez-González, A., Gutiérrez, F., and Machado, J., 1998. River response to Quaternary subsidence due to evaporite solution (Gállego River, Ebro Basin, Spain). Geomorphology 22, 243-263.

Blanco, E., Casado, M., Costa, M., Escribano, R., García Antón, M., Génova, M., Gómez, A., Moreno, J., Morla, C., Regato, P., and Sainz-Ollero, H., 1997. Los bosques ibéricos. Una interpretación geobotánica. Planeta, Barcelona, 572 pp.

Boessenkool, K.P., Brinkhuis, H., Schönfeld, J. and Targarona, J., 2001. North Atlantic seasurface temperature changes and the climate of western Iberia during the last deglaciation: a marine palynological approach. Global and Planetary Change 30, 3339.

Burjachs-Casas, F., Rodó, X, and Comín, F.A., 1996. Gallocanta: ejemplo de secuencia palinológica en una laguna efímera. In: Ruiz Zapata, B. (ed.) Estudios Palinológicos, XI Simposio de Palinología, Universidad de Alcalá. p. 25-29.

Capel Molina, J.J. ,1981. Los climas de España. Oikos-tau ediciones, Barcelona, 429 pp.

Carrión, J.S. and Dupré, M., 1996. Late Quaternary vegetational history at Navarrés, eastern Spain. A two core approach. New Phytologist 134, 177-191. 
Carrión, J.S., Munuera, M. and Navarro, C., 1998. The palaeoenvirnmental of Carihuela Cave (Granada, Spain): a reconstruction on the basis of palynological investigactions of cave sediments. Review of Palaeobotany and Palynology 99, 317-340.

COHMAP Members, 1988. Climatic changes of the last 18,000 years: observations and model simulations. Science 241, 1043-1052.

Davis, B.A.S.,1994. Paleolimnology and Holocene environmental change from endorheic lakes in the Ebro Basin, north-east Spain, Ph. D. Thesis, University of Newcastle Upon Tyne, $317 \mathrm{p}$

Digerfeldt, G., Olsson, S. and Sandgren, P. 2000. Reconstructionof lake level changes in Lake Xinias, central Greece during thelast 40,000 years. Palaeogeography. Palaeoclimatology, Palaeoecology 158: 65-82.

Diot, M.F., 1991. Le palynofacies en archéologia: intér^et de son etude. Révue Aquitania 4, 91-97.

García-Ruiz, J.M., Valero-Garcés, B., González-Sampériz, P., Lorent, A. Martí-Bono, C. , Begueria, S., and Edwards, L., 2001. Stratified scree in the Central Spanish Pyrenees: palaeoenvironmental implicationsPermaforst and Periglacial Processes 12, 233-242.

García-Vera, M.A., 1996. Hidrogeología de zonas endorreicas en climas semiáridos. Aplicación a Los Monegros (Zaragoza y Huesca). Diputación General de Aragón, Zaragoza, 297 pp.

Gasse, F. 2000. Hydrological changes in the African tropics since the Last Glacial Maximum. Quaternary Science Reviews 19, 189-211.

González-Sampériz, P., Valero-Garcés B., Martí, C., García-Ruiz, J.M., Lorente, A., Begueria, S., 2001. Holocene environmental change in the upper Gállego valley (Western Spanish Pyrenees): climate, environment and human impact. Terra Nostra 2001/2, $3^{\text {rd }}$ workshop SEWG, ELDP Girona, Spain, p. 37-41.

Harrison, S.P., Prentice, I.C., and Guiot, J., 1993. Climatic controls on Holocene lake-level changes in Europe. Climate Dynamics 8, 189-200.

Harrison, S.P., Yu, G. and Tarasov, P.E., 1996. Late Quaternary lake-level record from Northern Eurasia. Quaternary Research 45, 138-159. 
Huntley, B., 1988. Glacial and Holocene vegetation history: Europe. In: Huntley, B. and Webb, T. III (eds), Vegetation History, Kluwer, Dordrecht. p. 341-383.

Huntley, B., and Prentice, I. C., 1993. Vegetation and climates of Europe. In: Wright, H.E. Jr., Kutzbach, J.E., Webb, T.III, Ruddiman, W.F., Street-Perrot, F.A. and Bartlein, P.J. (eds). Global Climates since the Last Glacial Maximum. University Of Minnesota Press, Minneapolis, p. 136-167.

Huntley, B., Watts, W.A., Allen, J.R.M., and Zolitschka, B., 1999. Palaeoclimate, chronology and vegetation history of the Weishselian Lateglacial: comparative analysis of data from three cores at Lago Grande di Montichio, southern Italy. Quaternary Science Reviews 18, 945-960.

Jalut, G., Monserrat Martí, J., Fontgne, M., Delibrias, G., Vilaplanas, J.M., and Juliá, R., 1992. Glacial to interglacial vegetation changes in the northern and southern Pyrenees: deglaciation, vegetation cover and chronology. Quaternary Science Reviews 11, 449480.

Kutzbach, J.E., Guetter, P.J., Behling, P.J., and Selin, R., 1993. Simulated climatic changes: results of the COHMAP climate-model experiments. In: Wright, H.E. Jr., Kutzbach, J.E., Webb, T.III, Ruddiman, W.F., Street-Perrot, F.A., and Bartlein, P.J. (eds). Global Climates since the Last Glacial Maximum. University Of Minnesota Press, Minneapolis, p. 24-93.

Montserrat Martí, J., 1992. Evolución glaciar y postglaciar del clima y la vegetación en la vertiente sur del Pirineo. Geoforma Ediciones, Logroño, 115 p.

Pérez Obiol, R. and Juliá, R., 1994. Climatic Change on the Iberian Peninsula recorded in a 30,000-yr pollen record from Lake Banyoles. Quaternary Research 41, 91-98.

Peyron, O., Guiot, J., Cheddadi, R., Tarasov, P., Reille, M., de Beaulieu, J.L., Bottema, S \& Andrieu, V. 1998. Climatic reconstruction in Europe for 18,000 yr B.P. from pollen data. Quaternary Research 49, 183-196.

Pons, A. and Reille, M., 1988. The Holocene and Upper Pleistocene pollen record from Padul (Granada, Spain): a new study. Palaeogeography, Palaeoclimatology, Paleoecology $66,243-263$. 
Prentice, I.C, Guiot, J., \& Harrison, S.P., 1992. Mediterranean vegetation, lake levels and palaeoclimate at the Last Glacial Maximum. Nature 360, 658-660.

Pueyo-Mur, J.J., 1979. La precipitación evaporítica actual en las lagunas saladas del área Bujaraloz, Sástago, Caspe, Alcañiz y Calanda (provincias de Zaragoza y Teruel). Revista Institución Investigaciones Geológicas Diputación Provincial de Barcelona 33, 5 - 56.

Roberts, N. and Wright, H.E.,1993. Vegetation, Lake-level and climatic history of the Near East and Southwest Asia. In: Wright, H.E. Jr., Kutzbach, J.E., Webb ,T. III, Ruddiman, W.F., Street-Perrot, F.A., and Bartlein, P.J. (eds). Global Climates since the Last Glacial Maximum. University of Minnesota Press, Minneapolis, p. 94-220.

Samper-Calvete, F.J. and García-Vera M.A., 1998. Inverse modeling of groundwater flow in the semiarid evaporitic closed basin of Los Monegros, Spain. Hydrogeology Journal 6, 33-49.

Sánchez Goñi, M.F. and Hannon, G.E., 1999. High - altitude vegetational pattern on the Iberian Mountain Chain (north - central Spain) during the Holocene. The Holocene 9, $39-57$.

Sánchez-Goñi, M.F., Turon, J.L., Eynaud, F. and Gendreau, S., 2000. European climatic response to millennial scale changes in the Atmosphere-Ocean System during the last Glacial Period. Quaternary Research 54, 394-403.

Sánchez-Navarro, J.A., Pérez, A., Coloma, P., and Martínez-Gil, F.J., 1998. Combined effects of groundwater and eolian processes in the formation of the northernmost closed saline depression of Europe. North -East Spain, Hydrological Processes 12, 813-820.

Schütt, B., 1998. Reconstructions of Holocene paleoenvironments in the endorheic basin of Laguna de Gallocanta, Central Spain by investigation of mineralogical and geochemical characters from lacustrine sediments. Journal of Paleolimnology 20, 217 $-234$.

Stein, M., Starinsky, A., Katz, A., Goldstein, S.L., Machlus, M. and Schramm, A., 1997. Srisotopic, chemical and sedimentological evidence for the evolution of Lake Lisan and the Dead Sea. Geochim. et Cosmochim. Acta 61, 3975-3992. 
Talbot, M.R., 1990. A review of the palaeohydrological interpretation of carbon and oxygen isotopic ratios in primary lacustrine carbonates. Chemical Geology (Isotope Geoscience Section) 80, 261-279.

Tzedakis, P.C., 1994. Vegetation change through glacial-interglacial cycles: a long pollen sequence perspective. Philosophical Transaction Royal Society of London B, 345, 403432.

Utrilla, P. \& Rodanés, J.M. 1997. La actuación del hombre sobre el paisaje durante la Prehistoria en el Valle Medio del Ebro. In: Acción humana y desertificación en ambientes mediterráneos. García-Ruiz, J.M. \& López García, P. (eds.). Instituto Pirenaico de Ecología-CSIC. Zaragoza: 61-98.

Valero-Garcés, B.L., Delgado-Huertas, A., Navas, A.. Machin, J. González, P., and Kelts, K.,2000c. Quaternary palaeohydrological evolution of a playa lake: Salada Mediana, central Ebro Basin, Spain. Sedimentology. 47 (6), 1135-1156.

Valero-Garcés, B.L., González-Sampériz, P., Delgado-Huertas, A., Navas, A., Machín, J. y Kelts, K.,2000b. Late Glacial paleohydrology and vegetational change in Salada Mediana, Central Ebro Basin, Spain. Quaternary International 73/74, 29-46.

Valero-Garcés, B.L., Navas, A., Machin, J., Stevenson, T. \& Davis, B., 2000a. Responses of a saline lake ecosystems in semi-arid regions to irrigation and climate variability. The history of Salada Chiprana, Central Ebro Basin, Spain. Ambio 26 (6), 344-350.

Valero-Garcés, B.L., Zeroual, E., and Kelts, K.,1998. Arid phases in the western Mediterranean region during the Last Glacial Cycle reconstructed from lacustrine records. In: Benito, G., Baker, V.R., and Gregory, K.J. (eds.), Paleohydrology and Environmental Change. Wiley and Sons, London, p. 67-80.

van Zuidam, R.A., 1980. Un levantamiento geomorfológico de la región de Zaragoza. Geographicalia 6, 103-134.

Yu, G. and Harrison, S.P., 1995. Lake status record from Europe: Data base documentation. NOAA Paleoclimatology Publication Series Report 3, Boulder, pp 451. 


\section{FIGURE CAPTIONS}

Figure 1. Geographic location of the glacial records in the Central Ebro valley. A. Under modern climatic conditions, the region receives less than $300 \mathrm{~mm}$ per year of precipitation. B. Geological location of the three sites: La Salineta lake (S), the San Juan de Mozarrifar sequence (M) and the Valmadrid slope deposit (V). Z= Zaragoza

Figure 2. Main pollen taxa from the upper $3 \mathrm{~m}$ of La Salineta core sequence. Samples below $3 \mathrm{~m}$ were sterile.

Figure 3. La Salineta sedimentological, geochemical and isotopic record.

Figure 4. Cross plot of $\delta^{18} \mathrm{O}$ and $\delta{ }^{13} \mathrm{C}$ values distributed by main units in the La Salineta record. Covariance between $\delta^{18} \mathrm{O}$ and $\delta{ }^{13} \mathrm{C}$ is significant in units interpreted as deposited under more negative water balance.

Figure 5. San Juan de Mozarrifar sedimentological and palynological record.

Figure 6. Pollen assemblages from the Torrecilla de Valmadrid stratified slope deposits. 


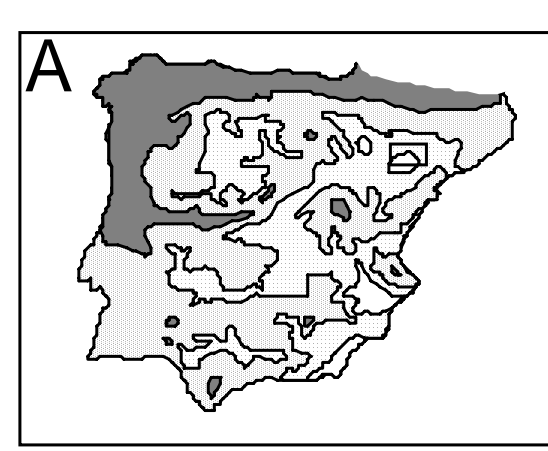

Anual rainfall

$\square \mathrm{P}<1000 \mathrm{~mm} \mathrm{yr}^{-1}$ $1000>\mathrm{P}>500 \mathrm{~mm} \mathrm{yr}^{-1}$ $500>\mathrm{P}>300 \mathrm{~mm} \mathrm{yr}^{-1}$ $<300 \mathrm{~mm} \mathrm{yr}^{-1}$

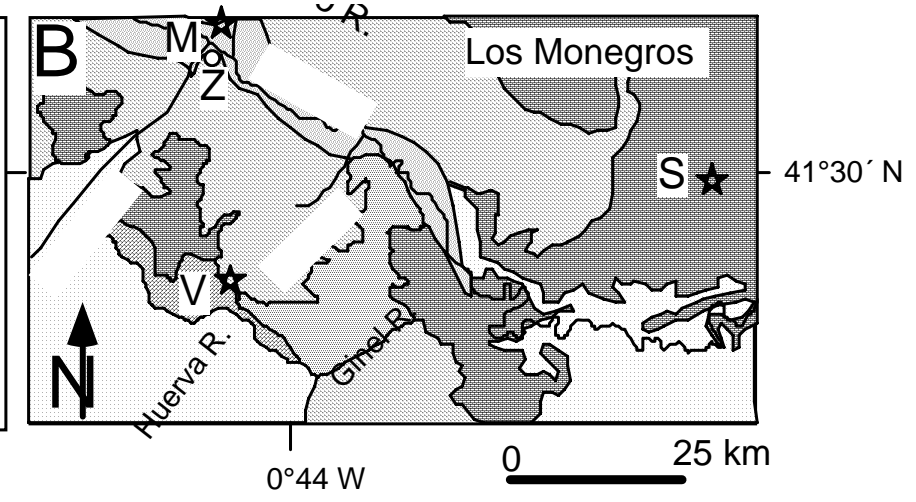

\section{Geological setting}

Ebro River

Quaternary deposits

$\square$ Carbonate Units Evaporite Units Claystone Units Sandstone Units Limestone Unit JURASSIC

FIGURE 1 


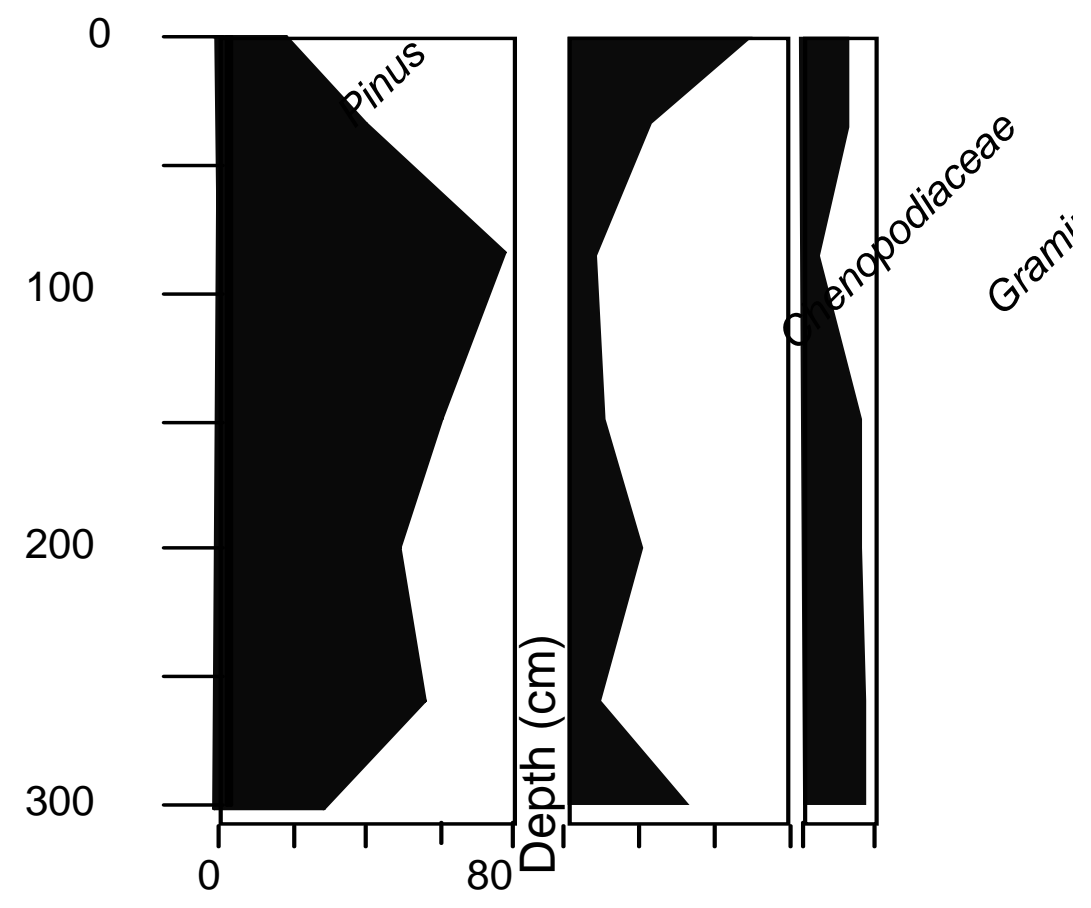

FIGURE 2 


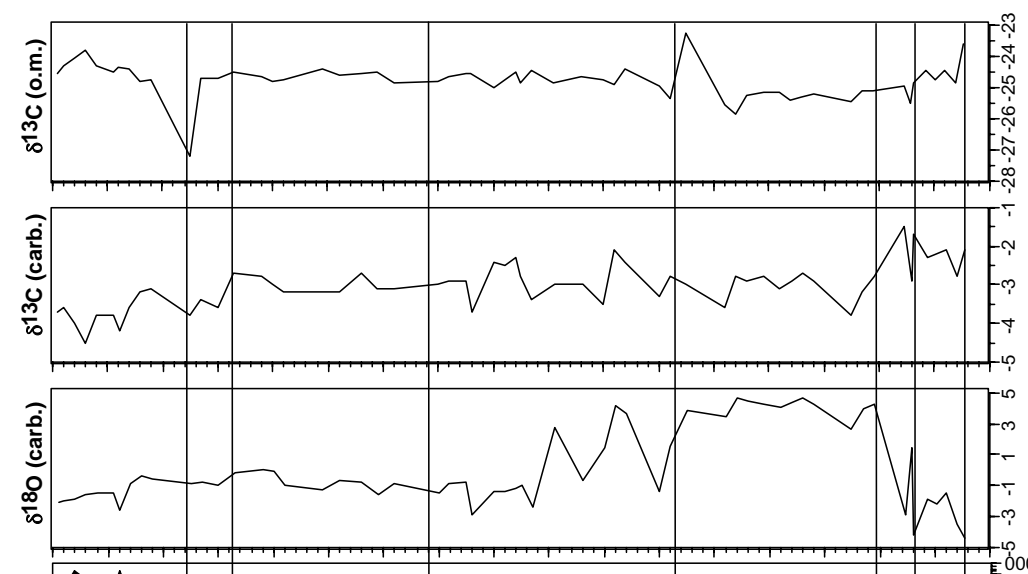

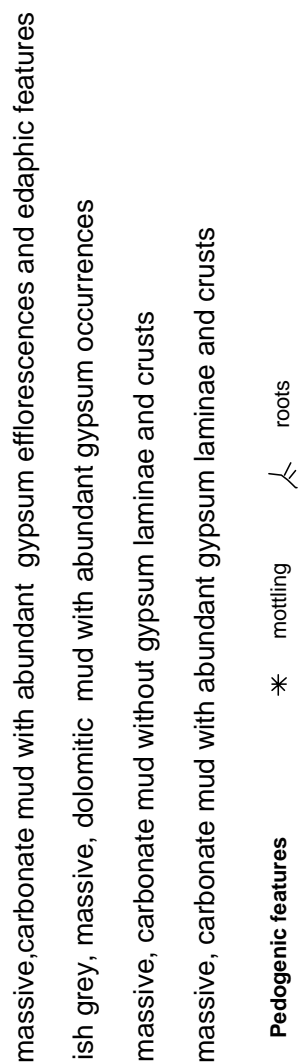

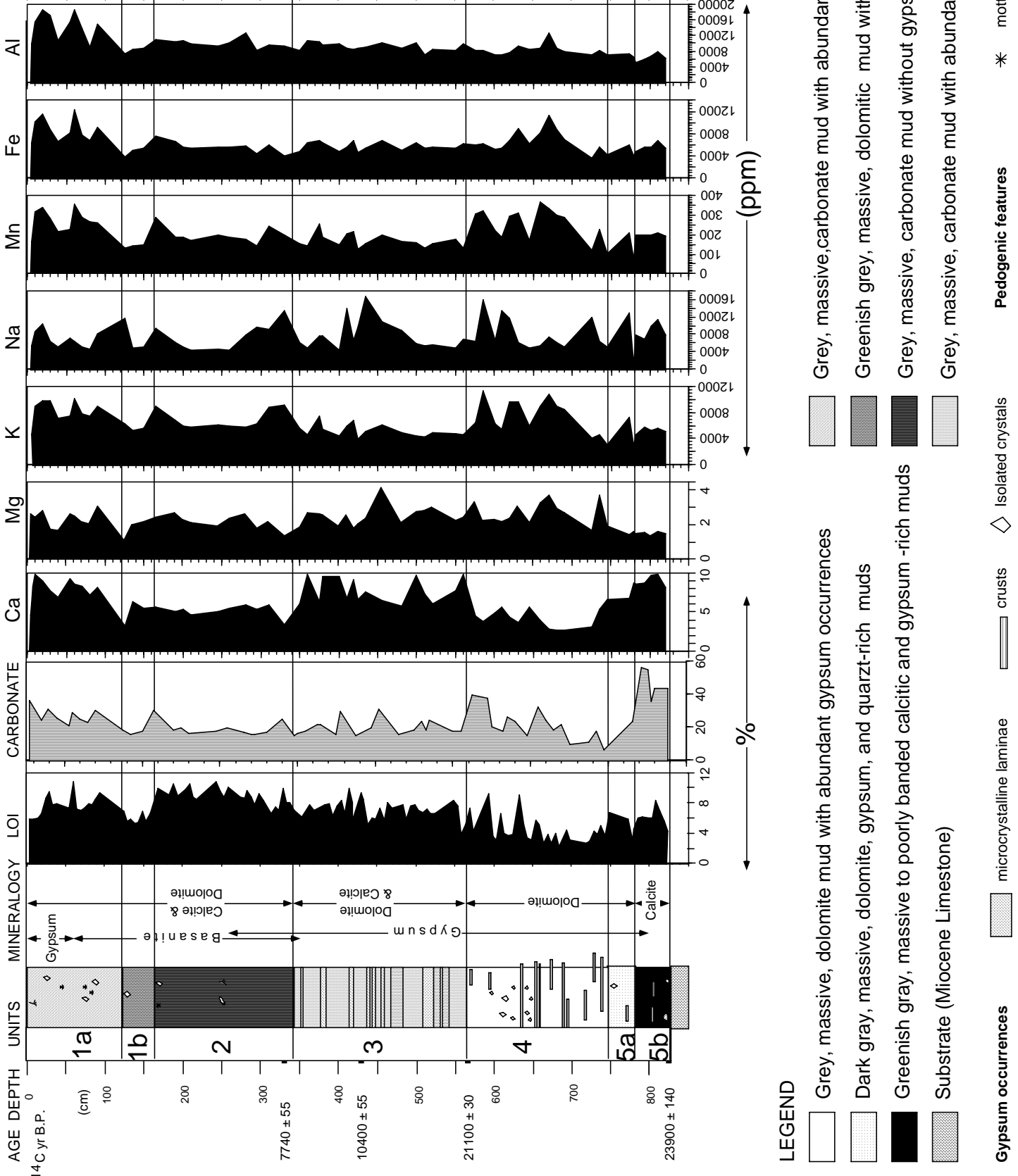

FIGURE 3 


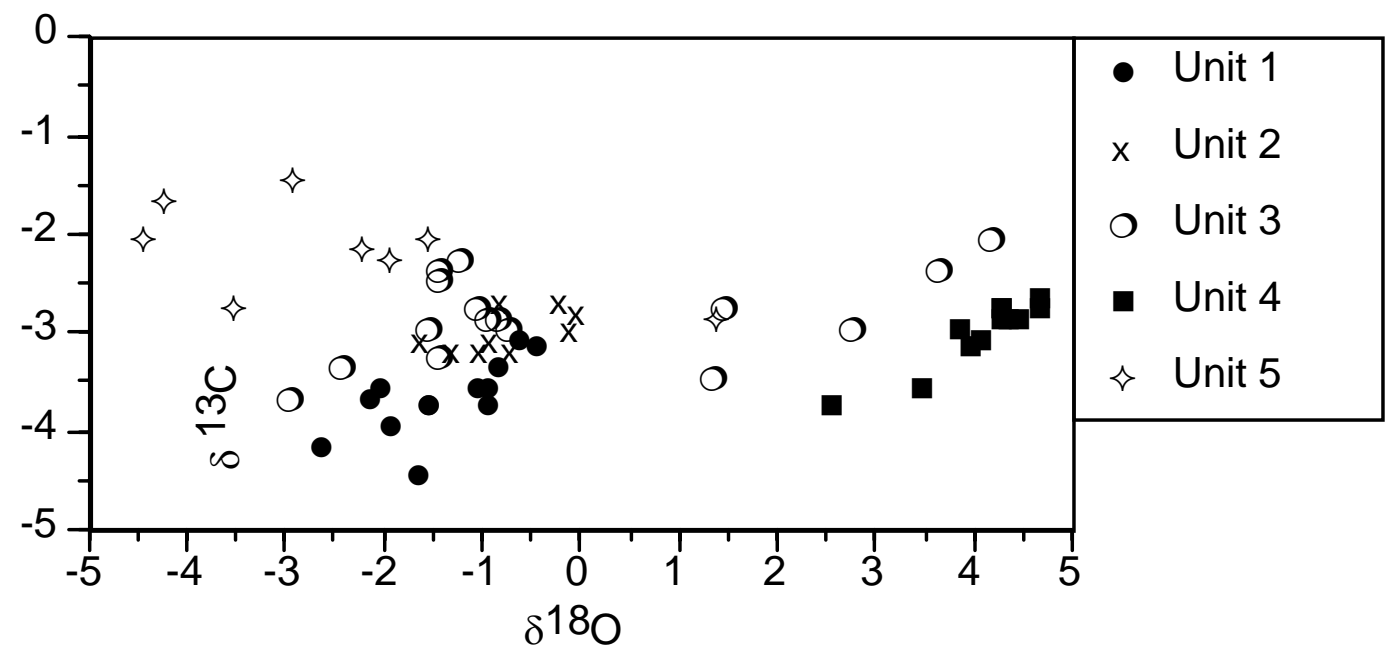

FIGURE 4 


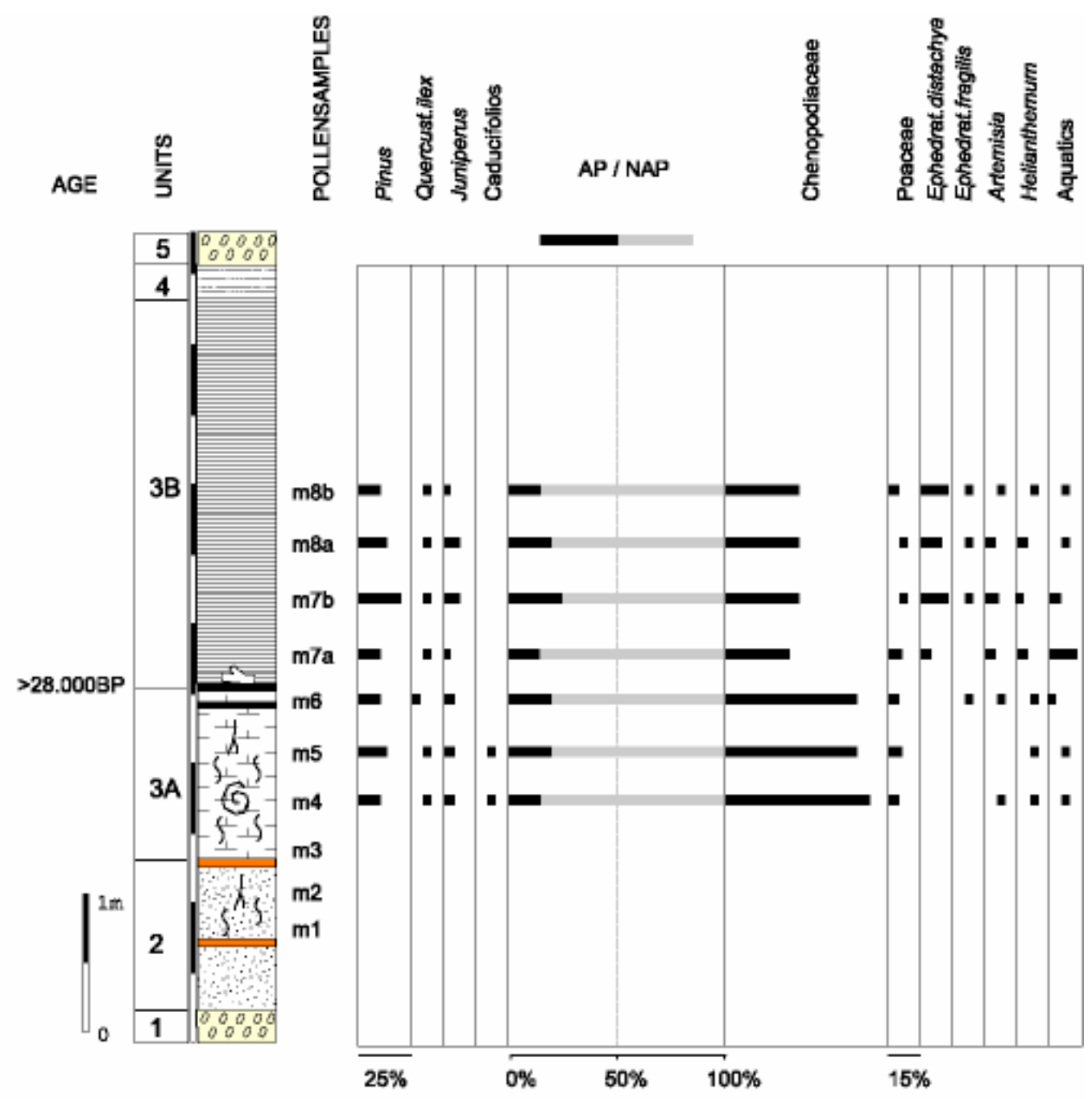

\section{LEGEND}

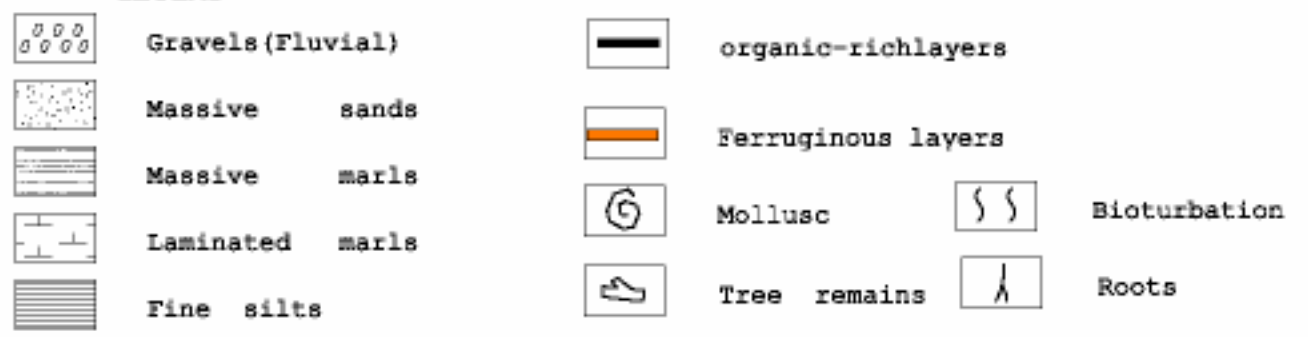

FIGURE 5 


\section{Figure 6}

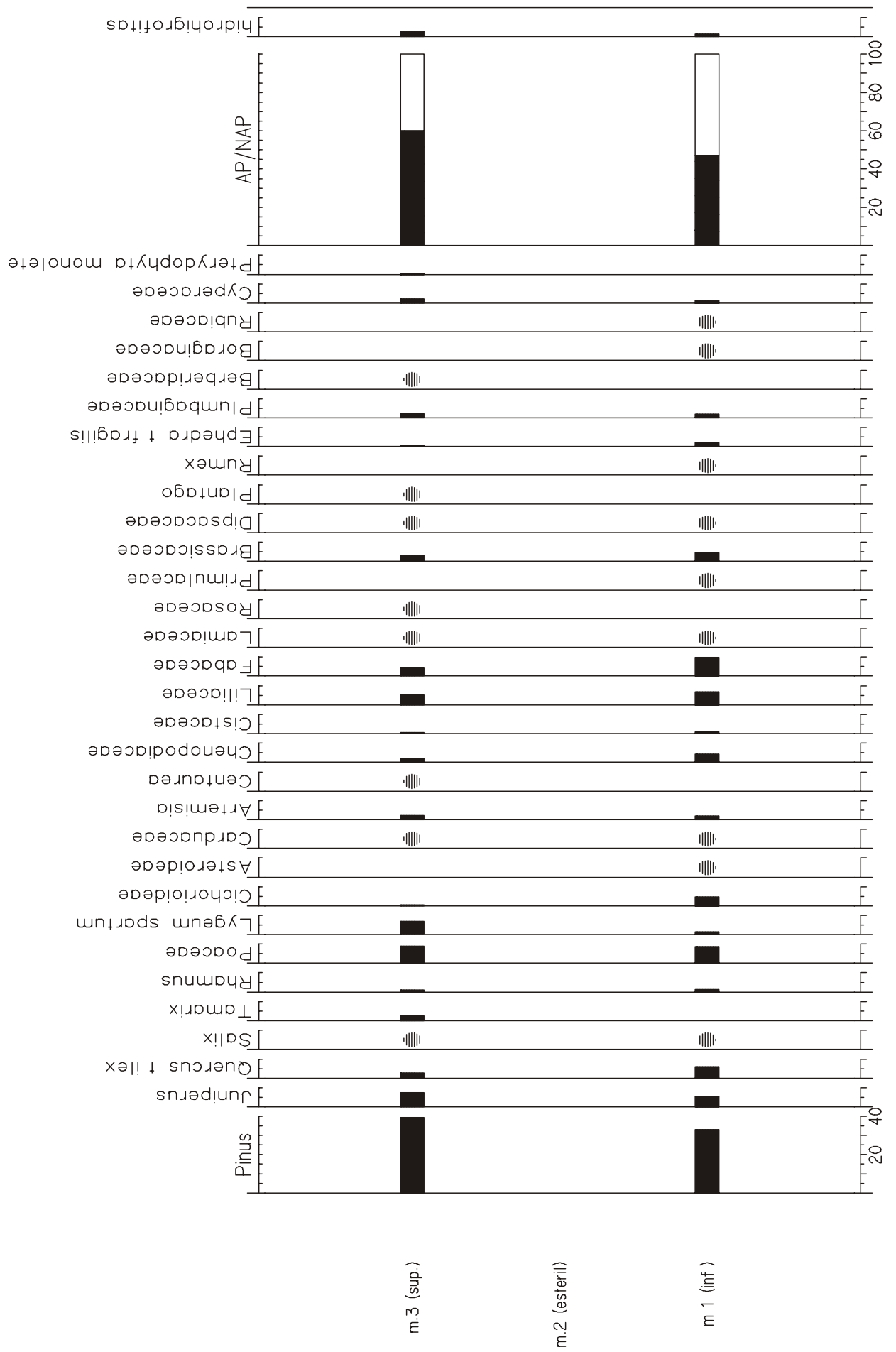

